
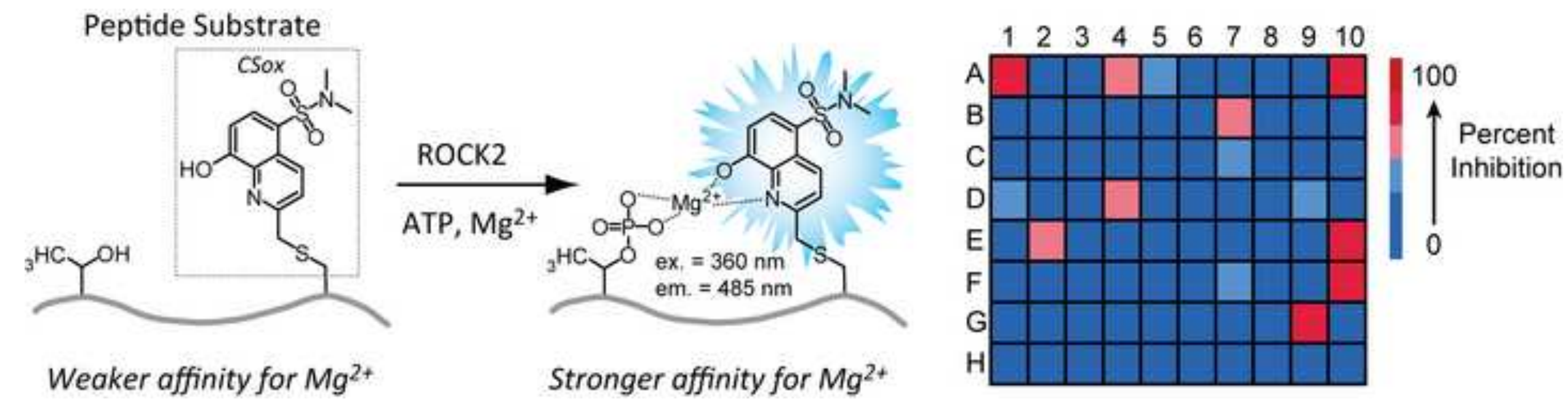


\title{
A Real-Time, Fluorescence-Based Assay for Rho-Associated Protein \\ Kinase Activity
}

Maia I. Kelly, ${ }^{\ddagger}$ Tyler J. Bechtel, ${ }^{\ddagger 1}$ D. Rajasekhar Reddy, ${ }^{2}$ Erome D. Hankore, Jon R. Beck, and Cliff I. Stains

\begin{abstract}
AUTHOR INFORMATION
Department of Chemistry, University of Nebraska - Lincoln, Lincoln, Nebraska 68588, United States
\end{abstract}

Corresponding Author

*E-mail: cstains2@unl.edu; phone: 1-402-472-2617

Current Addresses

1'Department of Chemistry, Boston College, Chestnut Hill, Massachusetts 02467, United States

${ }^{2}$ Department of Biochemistry and Molecular Biophysics, Washington University School of Medicine, St. Louis, Missouri 63110, United States

\section{Author Contributions}

$\ddagger$ These authors contributed equally to this work. 


\begin{abstract}
Inhibitors of Rho-associated protein kinase (ROCK) enzymatic activity have been shown to reduce the invasive phenotype observed in metastatic hepatocellular carcinoma (HCC). We describe the design, synthesis, and evaluation of a direct probe for ROCK activity utilizing a phosphorylation-sensitive sulfonamido-oxine fluorophore, termed Sox. The Sox fluorophore undergoes an increase in fluorescence upon phosphorylation of a proximal amino acid via chelation-enhanced fluorescence (CHEF, ex. $=360 \mathrm{~nm}$ and em. $=485 \mathrm{~nm})$, allowing for the direct visualization of the rate of phosphate addition to a peptide substrate over time. Our optimal probe design, ROCK-S1, is capable of sensitively reporting ROCK activity with a limit of detection of $10 \mathrm{pM}$ and a high degree of reproducibility ( $Z^{\prime}$-factor $=0.6$ at $100 \mathrm{pM}$ ROCK2). As a proof-of-principle for high-throughput screening (HTS) we demonstrate the ability to rapidly assess the efficacy of a 78 member, small molecule library against ROCK2 using a robotics platform. We identify two previously unreported ROCK2 inhibitor scaffolds, PHA665752 and IKK16, with $\mathrm{IC}_{50}$ values of $3.6 \mu \mathrm{M}$ and $247 \mathrm{nM}$ respectively. Lastly, we define conditions for selectively monitoring ROCK activity in the presence of potential off-target enzymes (PKC $\alpha$, PKA, and PAK) with similar substrate specificities.
\end{abstract}

\title{
Keywords
}

Kinase activity assay; Fluorescence-based biosensor; Rho-associated protein kinase; Inhibition; Small Molecule Screening

\begin{abstract}
Abbreviations
ROCK, rho-associated protein kinase; HCC, hepatocellular carcinoma; HTS, high-throughput screening; CHEF, chelation-enhanced fluorescence; Sox, sulfonamido-oxine; CSox, cysteine-
\end{abstract}


Sox; DTT, dithiothreitol; EGTA, ethylene glycol tetraacetic acid; PBS, phosphate-buffered saline; $K_{D}$, equilibrium dissociation constant. 


\section{Introduction}

The five-year survival rate for HCC is $15 \%$ [1], due in large part to the aggressive nature of the disease when diagnosed in the clinic. As a consequence, significant efforts are needed to both enhance early detection and develop approaches for inhibiting the metastatic phenotype of HCC. Towards the latter goal, protein kinases represent attractive candidates for inhibitor development [2-4] and subsequent clinical intervention [5-8]. Previous work has shed light on the signaling molecules responsible for the invasive phenotype observed in HCC [9, 10]. As a result of this work, ROCK has emerged as a potential target for inhibiting metastasis in HCC. ROCK1 and ROCK2 were originally identified as selective RhoA-GTP interacting proteins [1113] and share $89 \%$ homology between their respective kinase domains [14]. ROCK couples Rho activation with contractile force generation through the direct phosphorylation of LIM kinases $[15,16]$, the regulatory subunit of the myosin light chain [17, 18], and the myosinbinding subunit of myosin light chain phosphatase [17]. Together these phosphorylation events lead to productive cell movement [19]. Interestingly, two HCC cell lines (Li7 and KYN-2) were found to have increased cell motility in vitro that could be blocked using C3 exoenzyme, a Rho inhibitor [9]. Stable transfection of a dominant negative form of ROCK into these cell lines also decreased cell motility and metastatic rate in vivo compared to the parent cell lines. In addition, a small molecule inhibitor of ROCK activity, Y27632 [20], significantly impaired the ability of Li7 cells to form metastatic nodules in mice [10]. Overall, this work adds to the growing evidence that ROCK activity is necessary for the metastatic phenotype observed in HCC and that ROCK inhibitors could provide a means for interfering with the progression of HCC in the clinic.

In general, current protein kinase activity assays rely on the use of radioactivity or high-cost reagents and/or instrumentation [21, 22]. A variety of assay formats have been described that leverage the specificity and sensitivity of antibody-based reagents [23-25]. These techniques represent powerful approaches to monitoring kinase activity; however, the costs of these assay 
formats, and in certain cases the necessity of specialized equipment, can hinder their application in HTS. Alternatively, peptide-based kinase activity probes, capable of producing a change in fluorescence signal upon phosphorylation, can provide a straightforward, low-cost alternative for HTS [26-33]. As one example, the Imperiali laboratory has recently described the use of the phosphorylation-sensitive Sox fluorophore as a general platform for the design of sensitive serine/threonine and tyrosine kinase activity sensors [28, 29, 34, 35]. These Sox probes detect phosphorylation of a proximal residue through $\mathrm{CHEF}$ upon binding of $\mathrm{Mg}^{2+}$. However, initial Sox-based probe designs required deletion of sequences either $\mathrm{N}$ - or $\mathrm{C}$-terminal to the phosphorylation site in order to install a $\beta$-turn to allow for productive CHEF. To address this issue, a second generation probe design was envisioned in which a cysteine derivative, termed CSox, could be substituted for a native amino acid proximal to the site of phosphorylation [36]. These second generation CSox-based sensors allow for productive CHEF while necessitating only a single amino acid substitution in a peptide substrate (Fig. 1). As a consequence, CSox-based probes display tighter $\mathrm{K}_{M}$ values for their target kinases, allowing for the use of reduced sensor concentrations in assays [37-40]. CSox-based probes for protein kinase activity can be rapidly constructed using standard solid-phase peptide synthesis and can provide a direct, real-time readout of kinase enzymatic activity [41]. Moreover, the Dalby laboratory has recently demonstrated the use of CSox-based probes to identify inhibitors of eEF-2 from a HTS screen using 32,960 compounds [30]. This work demonstrates that CSoxbased probes can reduce the false positive rate associated with autofluorescence of inhibitors in HTS, since fluorescence changes are monitored over time as opposed to endpoint assays. The goal of the current work was to determine whether CSox could be employed to construct a sensitive and robust sensor for ROCK enzymatic activity, with the long term goal of utilizing this probe to discover novel ROCK inhibitors as well as interrogate ROCK activity in human disease states. 


\section{Experimental}

\subsection{General Reagents, instrumentation, and procedures}

Fluorescence assays were conducted using a BioTek SynergyH2 microplate reader. Assays were excited at $360 \mathrm{~nm}$ and the emission was recorded at $485 \mathrm{~nm}$. Reactions were incubated at $30{ }^{\circ} \mathrm{C}$ during fluorescence analysis. The plates used for fluorescence assays were either $384-$ well or 96-well half area plates (Corning: 3824 or 3992 respectively). The total volume for assays was $40 \mu \mathrm{L}$ (384-well plates) or $120 \mu \mathrm{L}$ (96-well plates). All assays were conducted in triplicate unless otherwise noted.

\subsection{Peptide synthesis}

Peptides were synthesized as previously described [41]. The peptides were purified using preparative reverse-phase HPLC and peptide identity was confirmed using ESI-MS (Table S1). To determine peptide concentration, the absorbance of each construct was measured and concentrations were calculated using the molar absorptivity of Sox, $8247 \mathrm{M}^{-1} \mathrm{~cm}^{-1}$ at $355 \mathrm{~nm}$ in 1 $\mathrm{mM} \mathrm{Na}{ }_{2}$ EDTA and $0.1 \mathrm{M} \mathrm{NaOH}$ [34].

\subsection{Determination of $\mathrm{Mg}^{2+}$ affinity and fold fluorescence increase}

Stock solutions of $\mathrm{Mg}^{2+}$ were prepared from Alfa Aesar Puratronic grade $\mathrm{MgCl}_{2}$ salt and standardized by titration with EDTA in the presence of Eriochrome Black $\mathrm{T}$. The $\mathrm{Mg}^{2+} \mathrm{K}_{\mathrm{D}}$ was determined by measuring the fluorescence of each construct in the presence of $0.5,1,5,10,50$, and $75 \mathrm{mM} \mathrm{MgCl}_{2}$ in a buffer containing $50 \mathrm{mM}$ Tris- $\mathrm{HCl}\left(\mathrm{pH}=7.5\right.$ at $\left.22{ }^{\circ} \mathrm{C}\right)$ and $150 \mathrm{mM} \mathrm{NaCl}$. Peptide was added to each assay at a final concentration of $1 \mu \mathrm{M}$. Fluorescence intensity was plotted and fit to a single site binding isotherm using Kaleidagraph to determine the $\mathrm{K}_{\mathrm{D}}$ using Eq. (1).

emission at $485 \mathrm{~nm}=\left(\mathrm{B}_{\max }{ }^{*}\left[\mathrm{Mg}^{2+}\right]\right) /\left(\mathrm{K}_{\mathrm{D}}+\left[\mathrm{Mg}^{2+}\right]\right)$ 
where $B_{\max }$ is the maximum specific binding in arbitrary fluorescence units and $\left[\mathrm{Mg}^{2+}\right]$ is the concentration of $\mathrm{Mg}^{2+}$.

The fold fluorescence increase of phospho- versus non-phospho-sensors was performed for each set of peptides. The $\mathrm{Mg}^{2+}$ concentrations used for each set of constructs were chosen based on the $K_{D}$ of the corresponding phospho-peptide. For each concentration of $\mathrm{Mg}^{2+}$, two concentrations of ATP were investigated $(0.1 \mathrm{mM}$ and $1 \mathrm{mM})$.

\subsection{Recombinant enzyme assays}

Recombinant ROCK2 (Life Technologies, PV3759), was diluted in enzyme dilution buffer: 50 $\mathrm{mM}$ Tris- $\mathrm{HCl}\left(\mathrm{pH}=7.5\right.$ at $\left.22{ }^{\circ} \mathrm{C}\right), 1 \mathrm{mM}$ EGTA, $0.01 \%$ Brij $(\mathrm{v} / \mathrm{v})$, and $10 \%$ glycerol $(\mathrm{v} / \mathrm{v})$. Kinase assays were conducted in a buffer containing: $50 \mathrm{mM}$ Tris- $\mathrm{HCl}\left(\mathrm{pH}=7.5\right.$ at $\left.22{ }^{\circ} \mathrm{C}\right), 0.1 \mathrm{mM}$ ATP, $1 \mathrm{mM}$ EGTA, $2 \mathrm{mM}$ DTT, $0.01 \%$ Brij $(\mathrm{v} / \mathrm{v})$, and the optimal $\mathrm{Mg}^{2+}$ concentration for each sensor. Assays were equilibrated to $30^{\circ} \mathrm{C}$ for twenty minutes before the addition of recombinant enzyme. Reaction velocities were determined by correcting for the loss of substrate fluorescence as previously described [34]. Kinetic parameters were determined by plotting reaction velocities as a function of substrate concentration and fitting to Eq. (2) in Kaleidagraph [42].

$$
\text { velocity }=\left(\mathrm{V}_{\max }{ }^{*}[\mathrm{~S}]\right) /\left(\mathrm{K}_{\mathrm{M}}+[\mathrm{S}]+\left([\mathrm{S}]^{2} / \mathrm{K}_{\mathrm{S}}\right)\right)
$$

where $\mathrm{V}_{\max }$ is the maximum velocity, $[\mathrm{S}]$ is the concentration of substrate, $\mathrm{K}_{\mathrm{M}}$ is the MichaelisMenten constant, and $\mathrm{K}_{\mathrm{S}}$ is the dissociation constant for substrate inhibition. The limit of detection for the assay was defined as the smallest concentration ROCK2 that produced a signal that was three standard deviations above assay noise.

Enzymes used in the panel assay were purchased through Life Technologies and diluted in enzyme dilution buffer. Where indicated the following inhibitor cocktail was added to the panel assays: PKItide (0.4 $\mu \mathrm{M})$, PKC inhibitor peptide $(4 \mu \mathrm{M})$, GF109203X (5 $\mu \mathrm{M})$, and calmidazolium $(4 \mu \mathrm{M})[35]$. 


\subsection{High-throughput screening}

Inhibitors were purchased from Tocris (3514) and supplied at $10 \mathrm{mM}$ in DMSO. Inhibitors were diluted with PBS to a working concentration of $1 \mathrm{mM}$ prior to screening. HTS assays were conducted using a robotics platform to prepare quadruplicate wells containing $1 \mathrm{nM}$ ROCK2, 5 $\mu \mathrm{M}$ ROCK-S1, $1 \mathrm{mM}$ ATP, $10 \mathrm{mM} \mathrm{MgCl}_{2}, 50 \mathrm{mM}$ Tris- $\mathrm{HCl}\left(\mathrm{pH}=7.5\right.$ at $\left.22{ }^{\circ} \mathrm{C}\right), 1 \mathrm{mM} \mathrm{EGTA}, 2$ $\mathrm{mM}$ DTT, $0.01 \%$ Brij $(\mathrm{v} / \mathrm{v})$, and $10 \mu \mathrm{M}$ of the indicated inhibitor. The final concentration of $10 \mu \mathrm{M}$ inhibitor was chosen in order to identify potential weak inhibitors. Wells with $10 \mu M$ GSK429286, no inhibitor, or no inhibitor and no enzyme were used as controls. Assays were performed in 384-well plates. Reactions slopes for each inhibitor were averaged and percent inhibition was calculated by comparison to controls. Two compounds from the initial 80 compound commercial library (TCS359 and SB431542) are not included in the final data analysis due to extremely high autofluorescence, at a concentration of $10 \mu \mathrm{M}$, which resulted in detector overload. We did not observe any effect from DMSO on the rate of phosphorylation in these assays. Reaction slopes were determined using the initial linear regions of fluorescence data; fits contained at least 15 points. 


\section{Results and discussion}

\subsection{Rational design and characterization of preliminary ROCK activity probes}

As a first step towards the development of a CSox-based ROCK activity sensor we set out to identify optimal peptide substrates for ROCK. Recent work from the Katayama laboratory has examined the ability of ROCK2 to phosphorylate a library of 136 peptides [43]. From this work, a sequence dubbed R22 was identified with a $\mathrm{K}_{\mathrm{M}}$ of $1.9 \mu \mathrm{M}$. We hypothesized that this sequence could be employed to generate a CSox-based chemosensor with low $\mu \mathrm{M}$ affinity for ROCK2 in order to allow for minimal sensor usage during HTS. Accordingly, we synthesized two CSoxbased activity probes using R22 as the template sequence with CSox placed at the +2 and -2 positions relative to the site of phosphorylation, ROCK-S1 and ROCK-S2 (Table 1). These two probe sequences represent important steps in sensor optimization, as previous work has demonstrated that the positioning of CSox in a peptide substrate sequence can dramatically alter the sensitivity of probe constructs [36, 40]. In addition, we synthesized the corresponding positive control sequences containing phospho-threonine at the site of phosphorylation, ROCKP1 and ROCK-P2 (Table 1).

Next, we measured the affinity of each peptide construct for $\mathrm{Mg}^{2+}$ (Fig. S1). Although positive control (phosphorylated) sequences are expected to display stronger affinities for $\mathrm{Mg}^{2+}$, it is important to quantify the difference in affinities of substrate and product sequences such that $\mathrm{Mg}^{2+}$ concentrations can be appropriately controlled for each construct [41]. Indeed, previous work from our laboratory has demonstrated that this optimization step can provide a dramatic enhancement in assay performance [40]. Using these experimentally determined $\mathrm{Mg}^{2+}$ affinities as a guide (Table 1), we measured the increase in fluorescence of each pair of product versus substrate peptides under varying $\mathrm{Mg}^{2+}$ and ATP concentrations (Table S2). Under optimized conditions, using $0.1 \mathrm{mM}$ ATP, we were able to obtain robust enhancements in probe fluorescence in response to phosphorylation (Table 1). Importantly, previous work has 
demonstrated that the $\mathrm{K}_{\mathrm{M}}$ of ROCK2 for ATP is $1.4 \mu \mathrm{M}$ [44], indicating that $0.1 \mathrm{mM}$ ATP could be used for enzymatic assays without severely interfering with the rate of substrate phosphorylation.

\subsection{Evaluation of probe efficiency for ROCK2}

Using the optimized $\mathrm{Mg}^{2+}$ and ATP concentrations identified above, we interrogated the preference of ROCK2 for the position of CSox within our probe sequences. Accordingly, we varied the concentration of each substrate and measured the resulting rate of product formation (Fig. 2). Interestingly, we observed substrate inhibition for each probe design at increasing sensor concentrations. These results highlight the importance of fully characterizing CSoxbased activity probes, as the use of higher concentrations $(>10 \mu \mathrm{M})$ of the sensors described in this paper would lead to diminished assay performance. Comparison of $k_{\text {cat }} / K_{M}$ for each sensor design indicated that ROCK-S1 was 188-fold more efficient for ROCK2. In particular, we observed a 33-fold decrease in probe turnover by positioning CSox at the -2 position relative to the site of phosphorylation in ROCK-S2. This indicates the sensitivity of ROCK2 to CSox at this position. Using these experimental results as a guide, we chose to employ ROCK-S1 at a concentration of $5 \mu \mathrm{M}$ for all subsequent experiments.

\subsection{ROCK-S1 limit of detection for ROCK2}

One significant source of cost during HTS is recombinant kinase. As a consequence, assays with low detection limits and high reproducibility are desirable. To determine the sensitivity of ROCK-S1, we measured sensor phosphorylation in the presence of decreasing amounts of ROCK2. These experiments indicated the ability to detect ROCK2 activity at concentrations as low as $10 \mathrm{pM}$ (Fig. 3). The trend line for this data is $y=701.7 x-4.1\left(R^{2}=0.9991\right)$, where $y$ is the average reaction slope in AFU/min and $x$ is the concentration of ROCK2 in nM. Moreover, these assays were highly reproducible $\left(Z^{\prime}\right.$-factor $=0.6$ at $0.1 \mathrm{nM}$ ROCK2), validating the use of ROCK-S1 for HTS [45]. 


\subsection{ROCK-S1 can report on ROCK2 inhibition}

As an initial test of whether ROCK-S1 could report on ROCK2 inhibition we assessed ROCKS1 phosphorylation in the presence of increasing concentrations of GSK429286, a wellcharacterized ATP-competitive ROCK2 inhibitor [46]. As expected, we observed a concentration dependent decrease in ROCK-S1 phosphorylation that correlated with the literature $\mathrm{IC}_{50}$ value of $63 \mathrm{nM}$ (Fig. 4) [47]. These data indicate the ability to straightforwardly monitor ROCK2 inhibition using ROCK-S1 in a 384-well format.

\subsection{Optimization of HTS conditions}

As a proof of principle for HTS using ROCK-S1 we chose to screen a commercially available 78 compound library of kinase inhibitors (Table S3). Importantly this library contains five known inhibitors of ROCK2; fasudil [48], Y27632 [20], HA1100 [49], H89 [50], and GW5074 [51] as well as the broad spectrum inhibitor Ro318220 [50]. Utilizing an automated robotics assay platform we assessed the percent inhibition of each compound in our library at a concentration of $10 \mu \mathrm{M}$ in quadruplicate 384-well plate assays (Fig. 5A). As expected, we observed $>50 \%$ inhibition of ROCK2 by fasudil, Y27632, HA1100, H89, GW5074, and Ro318220 (Fig. 5B). Interestingly, we also observed $>50 \%$ inhibition by two additional inhibitors (PHA665752 [52] and IKK16 [53]) that to the best of our knowledge have not been previously reported as ROCK2 inhibitors in the primary literature (Fig. 5B). To further investigate the potency of these inhibitors we obtained $I_{50}$ values for each of these scaffolds against ROCK2 (Fig. 6). Although these inhibitors displayed low $\mu \mathrm{M}$ to high $\mathrm{nM}$ potency for ROCK2 in the presence of $0.1 \mathrm{mM}$ ATP, the relatively high concentrations of inhibitors generally used during cell-based assays may lead to off-targets effects. As a consequence, the off-target effects of these inhibitors could have important ramifications for the interpretation of phenotypic assays. In the long term, the conditions outlined in this work could be used to screen larger compound or fragment libraries for novel ROCK2 inhibitor scaffolds. 


\subsection{Selectivity of ROCK-S1}

Another significant advantage of CSox-based activity sensors is the ability to selectively report on the activity of protein kinases in heterogeneous biological samples such as cell lysates and tissue homogenates $[37,38,54,55]$. However, in these complex samples off-target activity can be observed from enzymes with overlapping sequence specificity. In these situations off-target inhibitors have been effectively employed to reduce potential false positive signal in CSoxbased assays [35, 39, 41, 54]. As a first step towards defining conditions for monitoring ROCK activity in heterogeneous samples we assessed the selectivity of ROCK-S1 across a panel of protein kinases including ROCK2, ROCK1, PKCa, PKA, and PAK. Importantly, previous data demonstrated that the peptide sequence that serves as a template for ROCK-S1 could act as a substrate for PKCa, PKA, and PAK [15, 43]. Our data demonstrates that our CSox-based probe, ROCK-S1, could also be phosphorylated by PKA and PKCa (Fig. 7A). We next investigated whether PKA and PKCa activities could be suppressed with known inhibitors [35]. Accordingly we chose to employ well-characterized PKA and PKCa inhibitors: PKItide, PKC inhibitor peptide, calmidazolium, and GF109203X [35]. This inhibitor cocktail preserved a significant portion, $58 \%$, of ROCK2 activity (Fig. S2). However, the same inhibitor cocktail was capable of completely abolishing the off-target phosphorylation of ROCK-S1 (Fig. 7B). Although our panel does not contain every possible off-target enzyme present in cell lysates, this work represents an important first step towards defining conditions for the analysis of ROCK activity in complex biological samples such as cell lysates and tissue homogenates. Future experiments will be aimed at identifying optimized inhibitor cocktails that have a reduced effect on ROCK activity as well as accessing ROCK-S1 selectivity in cell lysates. 


\section{Conclusions}

Taken together, this work defines a new CSox-based probe along with optimized assay conditions for the direct analysis of ROCK2 activity. We have demonstrated the ability to utilize ROCK-S1 to rapidly screen inhibitor libraries in a 384-well plate format using an automated robotics system. This bioanalytical tool provides a straightforward approach to screening small molecule or fragment libraries for potential ROCK2 inhibitors. The ROCK2 inhibitor scaffolds identified in this study (PHA665752 and IKK16) could provide a starting point for the development of ROCK2 inhibitors, although the target specificity of these scaffolds would certainly need to be optimized. In addition, we have defined conditions that allow for the selective monitoring of ROCK activity in the presence of potential off-target enzymes. The sensitivity of ROCK-S1, 10 pM ROCK2, is on par with previously described Sox-based probes that have been successfully utilized to detect kinase activity in unfractionated cell lysates [34, $35,38,39,54]$. Consequently, our laboratory is currently investigating the use of ROCK-S1 to identify novel inhibitors of ROCK as well as interrogate ROCK activity perturbations in HCC. 


\section{Acknowledgments}

We acknowledge the Nebraska Center for Mass Spectrometry for assistance with peptide characterization and the HTS facility at the University of Nebraska Medical Center for assistance with proof-of-principle library screening. This work was funded by the Nebraska

Research Initiative, the Proposed Center for Integrated Biomolecular Communication, the Fred \& Pamela Buffett Cancer Center, and the Department of Chemistry at the University of Nebraska - Lincoln. T. J. Bechtel was supported by an NSF REU grant (1156560). 


\section{References}

[1] R. Siegel, D. Naishadham, A. Jemal, Cancer statistics, 2013, CA-Cancer J. Clin. 63 (2013) $11-30$.

[2] R.S. Vidadala, K.K. Ojo, S.M. Johnson, Z. Zhang, S.E. Leonard, A. Mitra, R. Choi, M.C. Reid, K.R. Keyloun, A.M. Fox, M. Kennedy, T. Silver-Brace, J.C. Hume, S. Kappe, C.L. Verlinde, E. Fan, E.A. Merritt, W.C. Van Voorhis, D.J. Maly, Development of potent and selective Plasmodium falciparum calcium-dependent protein kinase 4 (PfCDPK4) inhibitors that block the transmission of malaria to mosquitoes, Eur. J. Med. Chem. 74 (2014) 562-573.

[3] R.C. Murphy, K.K. Ojo, E.T. Larson, A. Castellanos-Gonzalez, B.G. Perera, K.R. Keyloun, J.E. Kim, J.G. Bhandari, N.R. Muller, C.L. Verlinde, A.C. White, Jr., E.A. Merritt, W.C. Van Voorhis, D.J. Maly, Discovery of Potent and Selective Inhibitors of Calcium-Dependent Protein Kinase 1 (CDPK1) from C. parvum and T. gondii, ACS Med. Chem. Lett. 1 (2010) 331-335. [4] S.M. Johnson, R.C. Murphy, J.A. Geiger, A.E. DeRocher, Z. Zhang, K.K. Ojo, E.T. Larson, B.G. Perera, E.J. Dale, P. He, M.C. Reid, A.M. Fox, N.R. Mueller, E.A. Merritt, E. Fan, M. Parsons, W.C. Van Voorhis, D.J. Maly, Development of Toxoplasma gondii calcium-dependent protein kinase 1 (TgCDPK1) inhibitors with potent anti-toxoplasma activity, J. Med. Chem. 55 (2012) 2416-2426.

[5] P. Cohen, Protein kinases--the major drug targets of the twenty-first century?, Nat. Rev. Drug Discov. 1 (2002) 309-315.

[6] P. Cohen, D.R. Alessi, Kinase drug discovery--what's next in the field?, ACS Chem. Biol. 8 (2013) 96-104.

[7] C.M. Gower, M.E. Chang, D.J. Maly, Bivalent inhibitors of protein kinases, Crit. Rev. Biochem. Mol. Biol. 49 (2014) 102-115.

[8] V. Lamba, I. Ghosh, New directions in targeting protein kinases: focusing upon true allosteric and bivalent inhibitors, Curr. Pharm. Des. 18 (2012) 2936-2945. 
[9] T. Genda, M. Sakamoto, T. Ichida, H. Asakura, M. Kojiro, S. Narumiya, S. Hirohashi, Cell motility mediated by rho and Rho-associated protein kinase plays a critical role in intrahepatic metastasis of human hepatocellular carcinoma, Hepatology 30 (1999) 1027-1036.

[10] M. Takamura, M. Sakamoto, T. Genda, T. Ichida, H. Asakura, S. Hirohashi, Inhibition of intrahepatic metastasis of human hepatocellular carcinoma by Rho-associated protein kinase inhibitor Y-27632, Hepatology 33 (2001) 577-581.

[11] T. Ishizaki, M. Maekawa, K. Fujisawa, K. Okawa, A. Iwamatsu, A. Fujita, N. Watanabe, Y. Saito, A. Kakizuka, N. Morii, S. Narumiya, The small GTP-binding protein Rho binds to and activates a $160 \mathrm{kDa}$ Ser/Thr protein kinase homologous to myotonic dystrophy kinase, EMBO J. 15 (1996) 1885-1893.

[12] T. Leung, E. Manser, L. Tan, L. Lim, A novel serine/threonine kinase binding the Rasrelated RhoA GTPase which translocates the kinase to peripheral membranes, J. Biol. Chem. 270 (1995) 29051-29054.

[13] T. Matsui, M. Amano, T. Yamamoto, K. Chihara, M. Nakafuku, M. Ito, T. Nakano, K.

Okawa, A. Iwamatsu, K. Kaibuchi, Rho-associated kinase, a novel serine/threonine kinase, as a putative target for small GTP binding protein Rho, EMBO J. 15 (1996) 2208-2216.

[14] G. Manning, D.B. Whyte, R. Martinez, T. Hunter, S. Sudarsanam, The protein kinase complement of the human genome, Science 298 (2002) 1912-1934.

[15] K. Ohashi, K. Nagata, M. Maekawa, T. Ishizaki, S. Narumiya, K. Mizuno, Rho-associated kinase ROCK activates LIM-kinase 1 by phosphorylation at threonine 508 within the activation loop, J. Biol. Chem. 275 (2000) 3577-3582.

[16] T. Sumi, K. Matsumoto, T. Nakamura, Specific activation of LIM kinase 2 via phosphorylation of threonine 505 by ROCK, a Rho-dependent protein kinase, J. Biol. Chem. 276 (2001) 670-676. 
[17] K. Kimura, M. Ito, M. Amano, K. Chihara, Y. Fukata, M. Nakafuku, B. Yamamori, J. Feng, T. Nakano, K. Okawa, A. Iwamatsu, K. Kaibuchi, Regulation of myosin phosphatase by Rho and Rho-associated kinase (Rho-kinase), Science 273 (1996) 245-248.

[18] G. Totsukawa, Y. Yamakita, S. Yamashiro, D.J. Hartshorne, Y. Sasaki, F. Matsumura, Distinct roles of ROCK (Rho-kinase) and MLCK in spatial regulation of MLC phosphorylation for assembly of stress fibers and focal adhesions in 3T3 fibroblasts, J. Cell Biol. 150 (2000) 797806.

[19] A.J. Ridley, Rho GTPases and cell migration, J. Cell Sci. 114 (2001) 2713-2722.

[20] M. Uehata, T. Ishizaki, H. Satoh, T. Ono, T. Kawahara, T. Morishita, H. Tamakawa, K. Yamagami, J. Inui, M. Maekawa, S. Narumiya, Calcium sensitization of smooth muscle mediated by a Rho-associated protein kinase in hypertension, Nature 389 (1997) 990-994. [21] C.J. Hastie, H.J. McLauchlan, P. Cohen, Assay of protein kinases using radiolabeled ATP: a protocol, Nat. Protoc. 1 (2006) 968-971.

[22] Y. Jia, C.M. Quinn, S. Kwak, R.V. Talanian, Current in vitro kinase assay technologies: the quest for a universal format, Curr. Drug Discov. Technol. 5 (2008) 59-69.

[23] J.M. Kolb, G. Yamanaka, S.P. Manly, Use of a Novel Homogeneous Fluorescent Technology in High Throughput Screening, J. Biomol. Screen. 1 (1996) 203-210.

[24] N. Ohmi, J.M. Wingfield, H. Yazawa, O. Inagaki, Development of a homogeneous timeresolved fluorescence assay for high throughput screening to identify Lck inhibitors: comparison with scintillation proximity assay and streptavidin-coated plate assay, J. Biomol. Screen. 5 (2000) 463-470.

[25] G. Warner, C. Illy, L. Pedro, P. Roby, R. Bosse, AlphaScreen kinase HTS platforms, Curr. Med. Chem. 11 (2004) 721-730.

[26] J.A. Gonzalez-Vera, Probing the kinome in real time with fluorescent peptides, Chem. Soc. Rev. 41 (2012) 1652-1664. 
[27] D.S. Lawrence, Q.Z. Wang, Seeing is believing: Peptide-based fluorescent sensors of protein tyrosine kinase activity, ChemBioChem 8 (2007) 373-378.

[28] D.M. Rothman, M.D. Shults, B. Imperiali, Chemical approaches for investigating phosphorylation in signal transduction networks, Trends Cell Biol. 15 (2005) 502-510.

[29] M.D. Shults, D. Carrico-Moniz, B. Imperiali, Optimal Sox-based fluorescent chemosensor design for serine/threonine protein kinases, Anal. Biochem. 352 (2006) 198-207.

[30] A.K. Devkota, M. Warthaka, R. Edupuganti, C.D.J. Tavares, W.H. Johnson, B. Ozpolat, E.J. Cho, K.N. Dalby, High-Throughput Screens for eEF-2 Kinase, J. Biomol. Screen. 19 (2014) 445452.

[31] S. Balakrishnan, N.J. Zondlo, Design of a protein kinase-inducible domain, J. Am. Chem. Soc. 128 (2006) 5590-5591.

[32] S.C. Zondlo, F. Gao, N.J. Zondlo, Design of an encodable tyrosine kinase-inducible domain: detection of tyrosine kinase activity by terbium luminescence, J. Am. Chem. Soc. 132 (2010) 5619-5621.

[33] K.D. Green, M.K.H. Pflum, Exploring Kinase Cosubstrate Promiscuity: Monitoring Kinase Activity through Dansylation, ChemBioChem 10 (2009) 234-237.

[34] M.D. Shults, B. Imperiali, Versatile fluorescence probes of protein kinase activity, J. Am. Chem. Soc. 125 (2003) 14248-14249.

[35] M.D. Shults, K.A. Janes, D.A. Lauffenburger, B. Imperiali, A multiplexed homogeneous fluorescence-based assay for protein kinase activity in cell lysates, Nat. Methods 2 (2005) 277283.

[36] E. Lukovic, J.A. Gonzalez-Vera, B. Imperiali, Recognition-domain focused chemosensors: versatile and efficient reporters of protein kinase activity, J. Am. Chem. Soc. 130 (2008) 1282112827. 
[37] E. Lukovic, E. Vogel Taylor, B. Imperiali, Monitoring protein kinases in cellular media with highly selective chimeric reporters, Angew. Chem. Int. Edit. 48 (2009) 6828-6831.

[38] L.B. Peterson, M.B. Yaffe, B. Imperiali, Selective Mitogen Activated Protein Kinase Activity Sensors through the Application of Directionally Programmable D Domain Motifs, Biochemistry 53 (2014) 5771-5778.

[39] C.I. Stains, E. Lukovic, B. Imperiali, A p38alpha-selective chemosensor for use in unfractionated cell lysates, ACS Chem. Biol. 6 (2011) 101-105.

[40] D.A. Szalewski, J.R. Beck, C.I. Stains, Design, synthesis, and evaluation of a selective chemosensor for leucine-rich repeat kinase 2, Bioorg. Med. Chem. Lett. 24 (2014) 5648-5651. [41] J.R. Beck, L.B. Peterson, B. Imperiali, C.I. Stains, Quantification of Protein Kinase Enzymatic Activity in Unfractionated Cell Lysates Using CSox-Based Sensors, Curr. Protoc. Chem. Biol. 6 (2014) 135-156.

[42] A. Fersht, Structure and mechanism in protein science: a guide to enzyme catalysis and protein folding, W.H. Freeman, New York, 1999.

[43] J.H. Kang, D. Asai, A. Tsuchiya, T. Mori, T. Niidome, Y. Katayama, Peptide substrates for Rho-associated kinase 2 (Rho-kinase 2/ROCK2), PloS One 6 (2011) e22699. [44] D. Vigil, T.Y. Kim, A. Plachco, A.J. Garton, L. Castaldo, J.A. Pachter, H. Dong, X. Chen, B. Tokar, S.L. Campbell, C.J. Der, ROCK1 and ROCK2 are required for non-small cell lung cancer anchorage-independent growth and invasion, Cancer Res. 72 (2012) 5338-5347.

[45] J.H. Zhang, T.D.Y. Chung, K.R. Oldenburg, A simple statistical parameter for use in evaluation and validation of high throughput screening assays, J. Biomol. Screen. 4 (1999) 6773.

[46] K.B. Goodman, H.F. Cui, S.E. Dowdell, D.E. Gaitanopoulos, R.L. Ivy, C.A. Sehon, R.A. Stavenger, G.Z. Wang, A.Q. Viet, W.W. Xu, G.S. Ye, S.F. Semus, C. Evans, H.E. Fries, L.J. Jolivette, R.B. Kirkpatrick, E. Dul, S.S. Khandekar, T. Yi, D.K. Jung, L.L. Wright, G.K. Smith, 
D.J. Behm, R. Bentley, C.P. Doe, E.D. Hu, D. Lee, Development of dihydropyridone indazole amides as selective Rho-kinase inhibitors, J. Med. Chem. 50 (2007) 6-9.

[47] R.J. Nichols, N. Dzamko, J.E. Hutti, L.C. Cantley, M. Deak, J. Moran, P. Bamborough, A.D. Reith, D.R. Alessi, Substrate specificity and inhibitors of LRRK2, a protein kinase mutated in Parkinson's disease, Biochem. J. 424 (2009) 47-60.

[48] T. Asano, I. Ikegaki, S. Satoh, Y. Suzuki, M. Shibuya, M. Takayasu, H. Hidaka, Mechanism of action of a novel antivasospasm drug, HA1077, J. Pharmacol. Exp. Ther. 241 (1987) 10331040.

[49] M. Arai, Y. Sasaki, R. Nozawa, Inhibition by the protein kinase inhibitor HA1077 of the activation of NADPH oxidase in human neutrophils, Biochem. Pharmacol. 46 (1993) 1487-1490. [50] S.P. Davies, H. Reddy, M. Caivano, P. Cohen, Specificity and mechanism of action of some commonly used protein kinase inhibitors, Biochem. J. 351 (2000) 95-105.

[51] J. Bain, L. Plater, M. Elliott, N. Shpiro, C.J. Hastie, H. Mclauchlan, I. Klevernic, J.S.C.

Arthur, D.R. Alessi, P. Cohen, The selectivity of protein kinase inhibitors: a further update, Biochem. J. 408 (2007) 297-315.

[52] J.G. Christensen, R. Schreck, J. Burrows, P. Kuruganti, E. Chan, P. Le, J. Chen, X.Y. Wang, L. Ruslim, R. Blake, K.E. Lipson, J. Ramphal, S. Do, J.R.J. Cui, J.M. Cherrington, D.B. Mendel, A selective small molecule inhibitor of c-Met kinase inhibits c-Met-dependent phenotypes in vitro and exhibits cytoreductive antitumor activity in vivo, Cancer Res. 63 (2003) 7345-7355.

[53] R. Waelchli, B. Bollbuck, C. Bruns, T. Buhl, J. Eder, R. Felfel, R. Hersperger, P. Janser, L. Revesz, H.G. Zerwes, A. Schlapbach, Design and preparation of 2-benzamido-pyrimidines as inhibitors of IKK, Bioorg. Med. Chem. Lett. 16 (2006) 108-112. 
[54] C.I. Stains, N.C. Tedford, T.C. Walkup, E. Lukovic, B.N. Goguen, L.G. Griffith, D.A.

Lauffenburger, B. Imperiali, Interrogating Signaling Nodes Involved in Cellular Transformations Using Kinase Activity Probes, Chem. Biol. 19 (2012) 210-217.

[55] M. Warthaka, C.H. Adelmann, T.S. Kaoud, R. Edupuganti, C.L. Yan, W.H. Johnson, S.

Ferguson, C.D. Tavares, L.J. Pence, E.V. Anslyn, P.Y. Ren, K.Y. Tsai, K.N. Dalby,

Quantification of a Pharmacodynamic ERK End Point in Melanoma Cell Lysates: Toward

Personalized Precision Medicine, ACS Med. Chem. Lett. 6 (2015) 47-52. 
Table 1. Sequences of ROCK Activity Probes

\begin{tabular}{lccc}
\hline Name & \multicolumn{1}{c}{ Sequence $^{\mathrm{a}}$} & $\mathrm{Mg}^{2+} \mathrm{K}_{\mathrm{D}}(\mathrm{mM})$ & $\begin{array}{c}\text { Fold Fluorescence } \\
\text { Enhancement }^{\mathrm{b}}\end{array}$ \\
\hline ROCK-S1 & KPARKKRYTV-CSOX-GNPYWM & 420 & 2.7 \\
ROCK-P1 & KPARKKRYpTV-CSox-GNPYWM & 17 & 7.0 \\
ROCK-S2 & KPARKK-CSox-YTVVGNPYWM & 66 & 7.1 \\
ROCK-P2 & KPARKK-CSox-YpTVVGNPYWM & 7.1 & \\
\hline aThe site of phosphorylation is shown in red and the position of CSox is highlighted in blue. & Fold \\
fluorescence enhancements are obtained by dividing the fluorescence of the phosphorylated peptide \\
by the fluorescence of the corresponding nonphosphorylated peptide. Assays were performed with 0.1 \\
mM ATP and the optimal concentration of $\mathrm{Mg}^{2+}$ for each sensor construct (10 and $10.5 \mathrm{mM} \mathrm{Mg}^{2+}$ for \\
ROCK-P1 and ROCK-P2 respectively).
\end{tabular}




\section{Figure Legends}

Fig. 1. A single amino acid in a peptide substrate is replaced with CSox (left). Phosphorylation of an adjacent amino acid leads to CHEF, which can be quantified by excitation at $360 \mathrm{~nm}$ and monitoring emission at $485 \mathrm{~nm}$ (right). The increase in fluorescence over time is proportional to kinase enzymatic activity.

Fig. 2. Kinetic parameters for ROCK-S1 (A) and ROCK-S2 (B) with ROCK2 (1 nM). Data were fit by using a modified form of the Michaelis-Menten equation,[42] given in the Experimental Section, in order to account for substrate inhibition.

Fig. 3. ROCK-S1 $(5 \mu \mathrm{M})$ phosphorylation as a function of ROCK2 concentration.

Fig. 4. ROCK-S1 $(5 \mu \mathrm{M})$ can report on the inhibition of ROCK2 $(0.5 \mathrm{nM})$ by a well-characterized ATP-competitive inhibitor.

Fig. 5. Proof-of-principle HTS for ROCK2 inhibitors. (A) Compounds (10 $\mu \mathrm{M})$ were assayed against ROCK2 $(1 \mathrm{nM})$ in the presence of $1 \mathrm{mM}$ ATP. Percent inhibition was calculated from quadruplicate assays. A complete compound list is given in the Table S3. Position A1 corresponds to $10 \mu \mathrm{M}$ GSK429286 (positive control) and position B1 represents no inhibitor (negative control). (B) Eight compounds from the library displayed >50\% ROCK2 inhibition. Six have been previously reported as ROCK2 inhibitors (grey bars) while two have, to the best of our knowledge, not been previously reported to inhibit ROCK2 (red bars).

Fig. 6. The indicated inhibitors were assayed against ROCK2 $(0.25 \mathrm{nM})$ and inhibition was monitored using ROCK-S1 $(5 \mu \mathrm{M})$ in the presence of $0.1 \mathrm{mM}$ ATP. Each scaffold displays low $\mu \mathrm{M}$ to high $\mathrm{nM}$ inhibition of ROCK2. 
Fig. 7. Selectivity of ROCK-S1 among a panel of protein kinases. (A) The phosphorylation of ROCK-S1 $(5 \mu \mathrm{M})$ in the presence of the indicated enzyme $(10 \mathrm{nM})$. (B) The same as panel A except the off-target inhibitors PKItide (0.4 $\mu \mathrm{M})$, PKC inhibitor peptide $(4 \mu \mathrm{M})$, GF109203X (5 $\mu \mathrm{M})$, and calmidazolium $(4 \mu \mathrm{M})$ are included. 


\section{Figures}

\section{Figure 1}

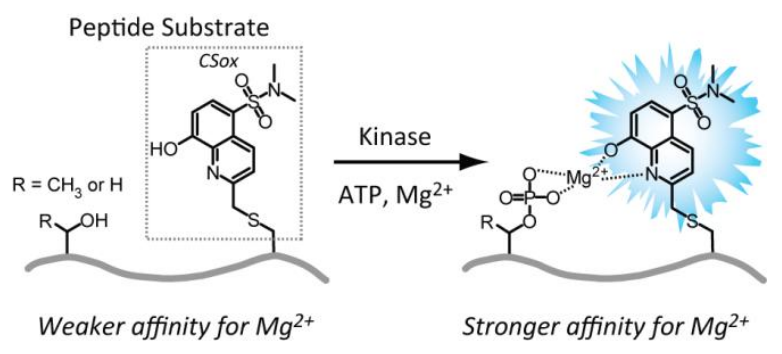


Figure 2
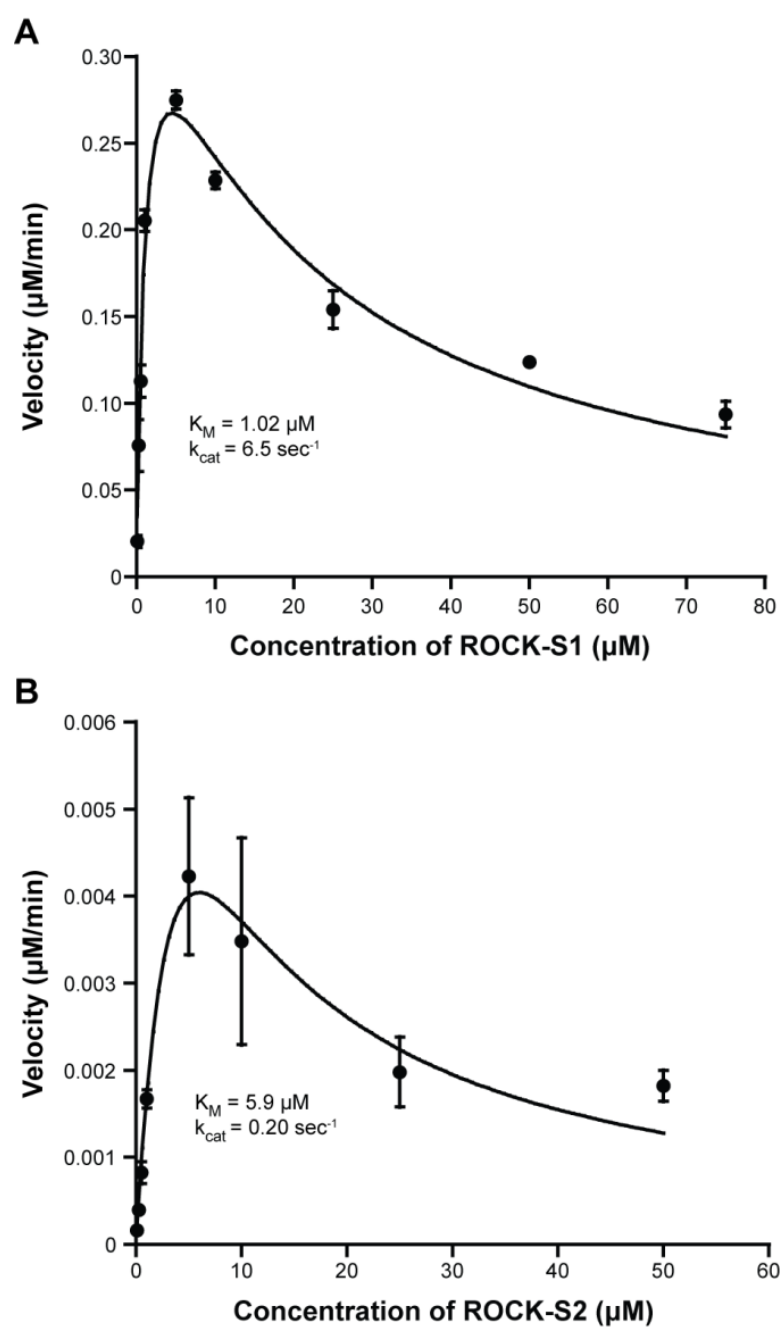

40 


\section{Figure 3}

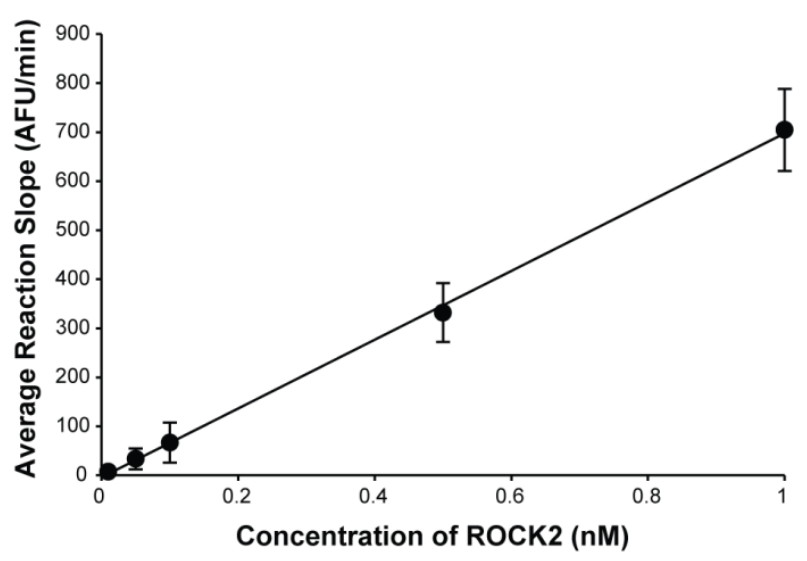


Figure 4

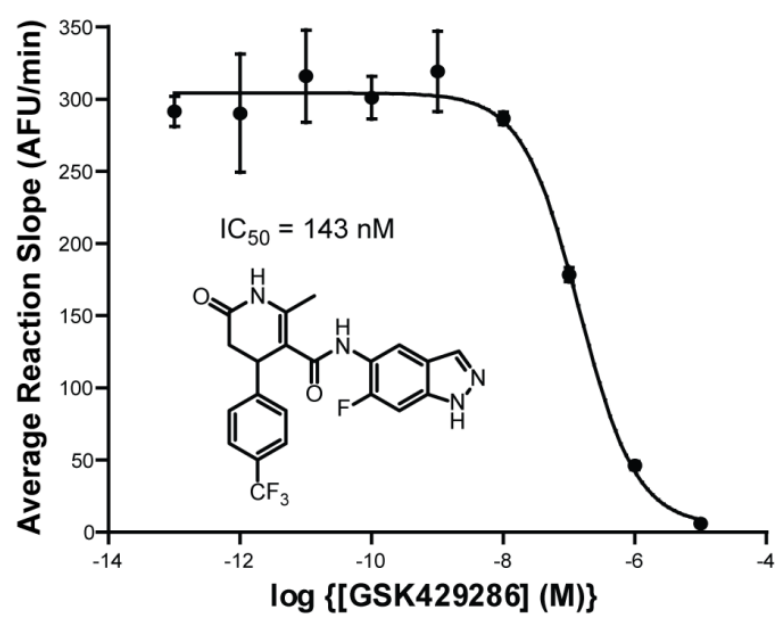

23

24

25

26

27

28

29

30

31

32

33

34

35

36

37

38

39

40

41

42

43

44

45

46

47

48

49

50

51

52

53

54

55

56

57

58

59

60

61

62

63

64

65 
Figure 5

A

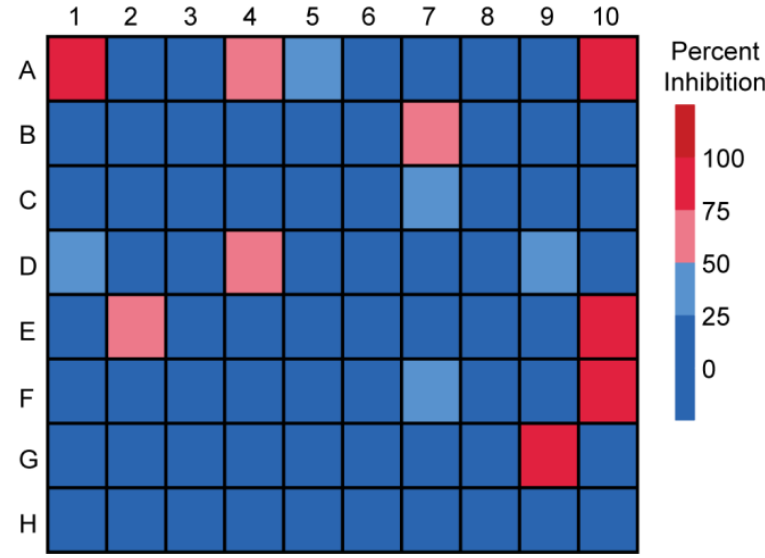

B

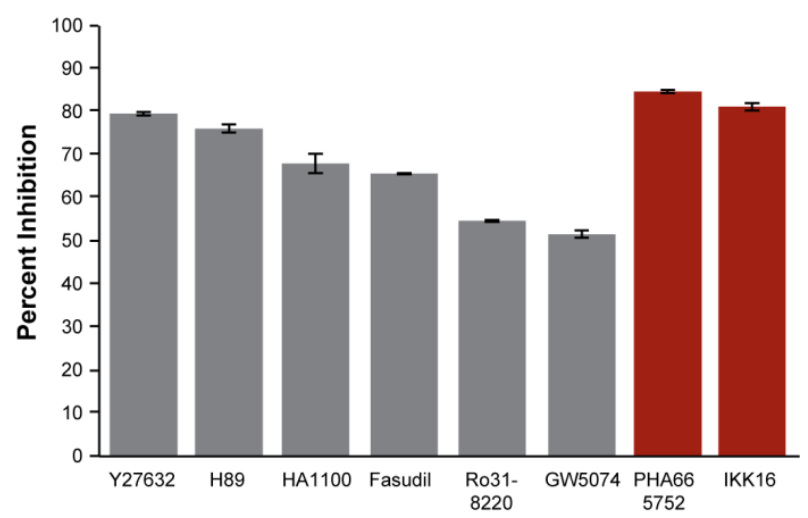

22

23

24

25

26

27

28

29

30

31

32

33

34

35

36

37

38

39

40

41

42

43

44

45

46

47

48

49

50

51

52

53

54

55

56

57

58

59

60

61

62

63

64

65 


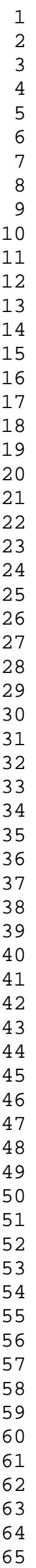

Figure 6

A

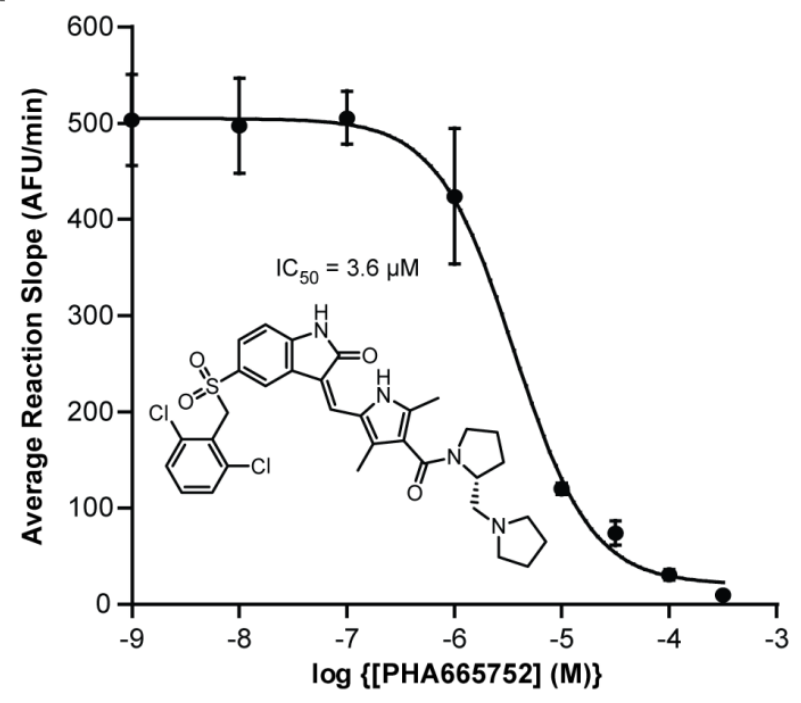

B

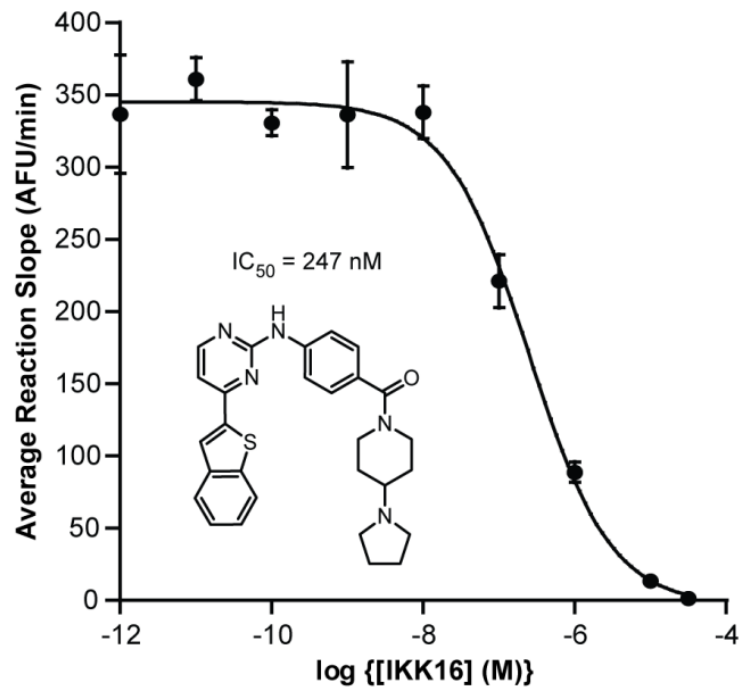

30 
Figure 7

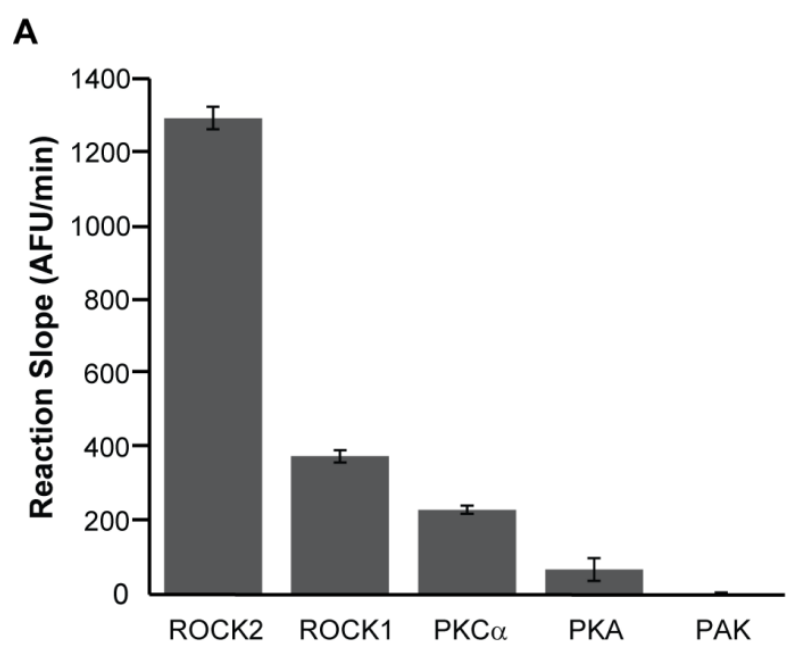

B

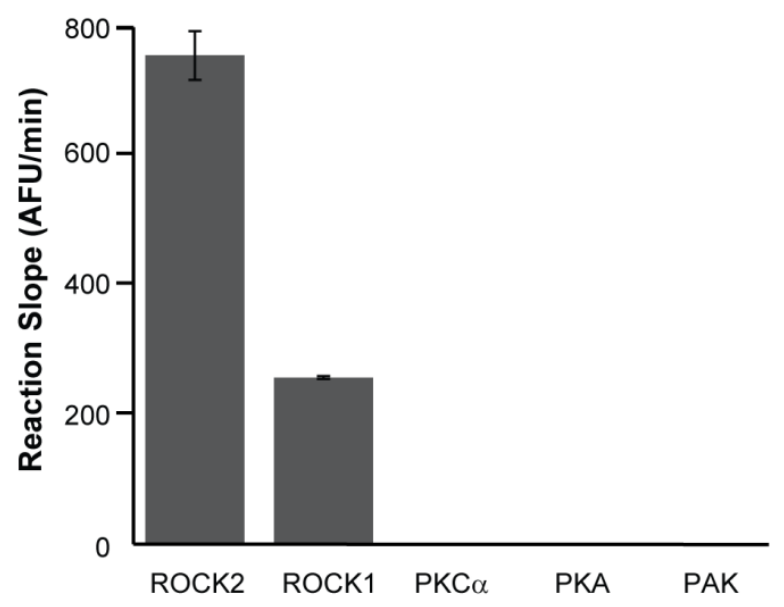

40 